\title{
A Framework for Sustainable Energy Policies: A Case of Pakistan
}

\author{
Maham Mujahid $^{1}$, Tanvir Ahmed ${ }^{2}$ \\ ${ }^{1,2}$ Pakistan Center for Advanced Studies in Energy, University of Engineering and Technology, Peshawar \\ mahammujahid1@gmail.com ${ }^{1}$ \\ Received: 08 September, Revised: 28 September, Accepted: 15 October
}

\begin{abstract}
In this paper the energy crisis of Pakistan is discussed with comparative analysis due to a continuous and wide gap among available system producing capacity and demand. The deteriorating of shortages (power) has become a main problem in the view of politics, showing the difficulties for persons and companies. It looms to weaken the reliability and legality of government and to additional pressure the societal fabric of the nation. The energy crisis did not arise suddenly. It is the straight consequence of impulsive and irresponsible energy policies over the last three years. These energy policies have obstructed the growth of low and plentiful domestic energy resources. They have also caused in very incompetent fuel mix selections, lack of energy and security of the economics. The country's energy insolvency is eventually due to huge official and failure of the governance. This paper analyzes the issues confronting Pakistan's energy sector and classifies the key elements of a hidden policy reply to address the nation's tough energy crisis. In order to assess these diverse renewable energy alternatives a comparative analysis of SAARC countries is performed using a standard criteria framework that are likely to be decisive in the making of decisions. The assessment shows that completely the renewable energy system conformations are not economically viable in the country while the renewable energy local resources could bring down the price of energy. An improved understanding of the whole processes by which innovation occurs is important, both theoretically and to inform the policy makers to support innovation to attain more sustainable technologies.
\end{abstract}

Keywords - Energy policy, sustainability, sustainable development, framework

\section{INTRODUCTION}

There is a dire requirement for an inclusive responsiveness and levitation of programs on renewable resource energy with distribution of satisfactory economical and other renewable resources that would make the overall public to grow, admit, and assist the extensive implementation of renewable resource energy and include the industries and other investors more extremely in gaining renewable resource energy. To improve access to data, the nationwide centers of information such as one stop shops on renewable resource energy should be recognized. These must be effortlessly accessible and extensively exposed by governments to deliver easy approach to fulfill the information on renewable energy scenarios, economical incentives, and needs and to deliver guidance to customers, investorss, and the public at huge. Besides energy policy, the technology, and structure development, the expansion of renewable resource energy includes sociopolitical and marketplaces and needs a systematic access covering entire issues. The governments should thus draw up inclusive schemes for generating a renewable resource energy industry and marketplaces involving the technology with the help of R\&D, demo projects, and commercialization, assisting infrastructure, economical mechanisms, and the utilization of instruments that are based on market such as the renewable resource portfolio standards, green costs, the design of feed-in tariffs, system of net metering, along with renewable energy certificates that are tradable [1].

\section{LITERATURE REVIEW}

The showing up of the security of energy supply is determined by keeping in opinion some facts which comprises of dependence on imports, reliance on imports of solid fuels, dependability on imports of oil, dependence on natural gas imports, variation of primary fuel, diversity of fuel of electrical energy generation, reliance of energy fuel and planned supplies of oil. The goal of energy supply security should be to restrict the threats involved in relying of imports or exterior sources supply [1].

The development of renewable energy resources in the SAARC countries is incomplete due to many problems which comprises economic difficulties in which the renewable technology is expensive than the traditional ones. Likewise, the ambiguity in policies and procedures including the slow procedures of approval by managers, financial, dearth of skills and awareness are few other problems in the way of progress of renewables in SAARC states. These can be fixed with the seriousness of the local markets and with the sale economies which will drive to the lesser rate of renewable resources. The FIT i.e. feed in-tariff and the renewable support mechanism are the two for aid of renewables should be applied with other policies to provide it with best consequences [2]

Nigeria is a country which has plentiful reserves of renewables, but they are fronting the wasteful use of energy for which their policy is to support the evolvement of an energy combination that will point out the safeguarding of petroleum reserves in such a way that will allow their sustained exportation for foreign incomes for as many months as probable. The numerous areas where conservation in energy 
can be done should be recognized to safe energy. As observed in quite a number of wealthy countries supporting renewable energy resources such as Japan, Denmark and Germany a durable and enduring commitment from the government is vital in applying any type of policies which will lead to the development of renewable resources, in specific, and a sustainable change, in wide term [3].

The ideologies that offer significant guidelines to the development of energy security strategy are "Cost allocation" denotes to the detail that to confirm risk minimization all recipients require to share the total security charges justly. This involves illustrating who will get what assistances. "Lessing the cost" refers to escaping of over-obliging to any one track or protection policy and that risk reduction should not put an extreme burden on civilization. "Varied-dimensionality or multi-aims" refers to the statistic that risk reduction should be considered to deal with many kinds of risks, not only one or two. "Suppleness or to switch" refers to the necessity for any strong security strategy to adjust to exterior deviations. Lastly, "expectancy of non-reoccurrence" mentions to the detail that though security prices may not produce any visible coming back, the insurance providing is vital [4].

In evolving countries, high-tech jumping to the use of very competent applications, equipment, procedures, automobiles, and transportation systems proposes substantial potential for energy effectiveness enhancements. To ease the energy poverty in emerging countries there should be creativities taken to advance health and intensify productivity by providing worldwide access to suitable energy facilities especially for illumination, transport and cookery through inexpensive, highsuperiority, harmless, and environmentally suitable energy haulers and end-use strategies. The commercial energy should be made accessible to upsurge income-producing chances [5].

\section{RESEARCH MethodOLOGY}

TABLE. 1

\begin{tabular}{|l|l|}
\hline Criteria Points & Explanation \\
\hline $\begin{array}{l}\text { Renewable } \\
\text { energy } \\
\text { development }\end{array}$ & $\begin{array}{l}\text { A renewable portfolio } \\
\text { standard is a special } \\
\text { tool for policy making } \\
\text { [6]. The leaders in the } \\
\text { alteration of the energy } \\
\text { system is Germany [7]. }\end{array}$ \\
\hline $\begin{array}{l}\text { Specific } \\
\text { in tariff }\end{array}$ & $\begin{array}{l}\text { Feed-in tariffs system } \\
\text { approach is more } \\
\text { effective than a system } \\
\text { of bidding [8]. } \\
\text { Germany, in specific, } \\
\text { have shown that feed- } \\
\text { in tariffs can be utilized } \\
\text { as a powerful tool of } \\
\text { policy to drive } \\
\text { renewable resource } \\
\text { energy deployment [9]. }\end{array}$ \\
\hline & $\begin{array}{l}\text { Diversification and } \\
\text { localization of energy }\end{array}$ \\
\hline
\end{tabular}

\begin{tabular}{|c|c|}
\hline $\begin{array}{l}\text { Localization } \\
\text { of resources }\end{array}$ & $\begin{array}{l}\text { resources would also } \\
\text { offer a security for the } \\
\text { energy demand and } \\
\text { supply along with } \\
\text { distribution as well for } \\
\text { the energy customers } \\
{[10] \text {. In the energy }} \\
\text { sector, renewable } \\
\text { resources mainly } \\
\text { lessen the need of gas } \\
\text { or coal importation as } \\
\text { oil use is restricted in } \\
\text { this area [11]. }\end{array}$ \\
\hline $\begin{array}{l}\text { Diversifying } \\
\text { resources }\end{array}$ & $\begin{array}{l}\text { If the government is } \\
\text { not to weaken the } \\
\text { importance it has } \\
\text { conventionally } \\
\text { attached to electricity } \\
\text { supply variety, it seems } \\
\text { from this exercise that } \\
\text { it should readjust } \\
\text { intervention to the } \\
\text { assistance of } \\
\text { renewables rather than } \\
\text { nuclear energy [12]. } \\
\text { Investments in } \\
\text { renewable energy } \\
\text { resources also } \\
\text { outgrowth innovation } \\
\text { and job development } \\
{[13] \text {. }}\end{array}$ \\
\hline $\begin{array}{l}\text { Government } \\
\text { economic } \\
\text { framework } \\
\text { (affordable } \\
\text { price of } \\
\text { energy) }\end{array}$ & $\begin{array}{l}\text { The recognized } \\
\text { objective of the energy } \\
\text { shift is to lessen } \\
\text { Germany's greenhouse } \\
\text { gas emissions by eighty } \\
\text { to above ninety percent } \\
\text { from } 1990 \text { levels by } \\
2050 \text { without } \\
\text { depending on the } \\
\text { power of nuclear } \\
\text { energy and while } \\
\text { keeping secure and } \\
\text { affordable energy } \\
\text { approach [14]. The } \\
\text { pricing policies such as } \\
\text { carbon tax and cash } \\
\text { allowances fos } \\
\text { renewable resource } \\
\text { investments may not } \\
\text { yield the desired } \\
\text { consequences, and a } \\
\text { high level of carbon tax } \\
\text { may lessen the } \\
\text { renewable energy } \\
\text { resource investments, } \\
\text { and cash allowances to } \\
\text { renewable resources }\end{array}$ \\
\hline
\end{tabular}




\begin{tabular}{|c|c|}
\hline & $\begin{array}{l}\text { may rise emissions of } \\
\text { carbon [15]. }\end{array}$ \\
\hline $\begin{array}{l}\text { Reduction of } \\
\text { fossil fuels }\end{array}$ & $\begin{array}{l}\text { Renewable resource } \\
\text { energy aids contribute } \\
\text { to substitute the small- } \\
\text { carbon transition but } \\
\text { can suggest distributive } \\
\text { properties, conditional } \\
\text { on the way in which } \\
\text { they are applied [16]. } \\
\text { Generally, enforced } \\
\text { early departures of } \\
\text { fossil fuel resource } \\
\text { generation in deep } \\
\text { decarbonization } \\
\text { situations bring a } \\
\text { multitude of } \\
\text { complications globally } \\
\text { and provincially [17]. } \\
\text { The future energy } \\
\text { system of Denmark is } \\
\text { putting stress on energy } \\
\text { efficiency, reduction of } \\
\text { carbon dioxide, and } \\
\text { industrial expansion } \\
\text { [18]. }\end{array}$ \\
\hline $\begin{array}{l}\text { Fostering } \\
\text { innovation }\end{array}$ & $\begin{array}{l}\text { Presenting green } \\
\text { energy market will } \\
\text { make it likely for the } \\
\text { new renewable energy } \\
\text { technologies to be } \\
\text { partially economically } \\
\text { rewarded for the } \\
\text { ecological profits, } \\
\text { which they make } \\
\text { compared to traditional } \\
\text { energy production } \\
\text { [19]. The discoveries } \\
\text { of Bergek and } \\
\text { Jacobsson's analysis } \\
\text { of German, Swedish } \\
\text { and Dutch wind turbine } \\
\text { industries that policy } \\
\text { makers requires to be } \\
\text { mindful of the } \\
\text { complication } \\
\text { innovation structures } \\
\text { and the range of works } \\
\text { that these systems } \\
\text { offer, in order to } \\
\text { progress the design of } \\
\text { the mix of policy tools } \\
\text { needed to encourage } \\
\text { fruitful innovation } \\
\text { system [20]. }\end{array}$ \\
\hline $\begin{array}{l}\text { Energy } \\
\text { security }\end{array}$ & $\begin{array}{l}\text { A lot of nations have } \\
\text { adopted to diversify } \\
\text { energy supply policy in }\end{array}$ \\
\hline
\end{tabular}

\begin{tabular}{|c|c|}
\hline & $\begin{array}{l}\text { their energy security } \\
\text { plan to control the } \\
\text { import risk and price of } \\
\text { energy to make sure } \\
\text { that sufficient energy } \\
\text { can be gained at } \\
\text { reasonable cost level } \\
{[21] \text { Energy is }} \\
\text { unavoidable for human } \\
\text { lifespan and a safe and } \\
\text { reachable supply of } \\
\text { energy is vital for the } \\
\text { sustainability of } \\
\text { modern civilizations. } \\
\text { Renewable resource } \\
\text { energy sector, } \\
\text { presently meeting } \\
13.5 \% \text { of the } \\
\text { worldwide energy } \\
\text { demand, is now rising } \\
\text { faster than the } \\
\text { development in overall } \\
\text { market of energy [22]. }\end{array}$ \\
\hline $\begin{array}{l}\text { Establishment } \\
\text { of wind } \\
\text { energy } \\
\text { resources }\end{array}$ & $\begin{array}{l}\text { The demand side } \\
\text { strategies are required } \\
\text { to encourage not only } \\
\text { dissemination of wind } \\
\text { resource energy, but } \\
\text { novelty in the } \\
\text { technology expertise } \\
\text { itself [23]. Nowadays, } \\
\text { about 50 percent of } \\
\text { both the Danish } \\
\text { electricity and heat } \\
\text { demand are fashioned } \\
\text { in combined heat and } \\
\text { power production and } \\
\text { more than } 15 \text { percent of } \\
\text { the energy demand is } \\
\text { produced by wind } \\
\text { turbines. Equally both } \\
\text { technologies are } \\
\text { important for the } \\
\text { implementation of } \\
\text { Danish climate change } \\
\text { response aims [24]. }\end{array}$ \\
\hline $\begin{array}{l}\text { Broadening } \\
\text { industrial } \\
\text { capabilities }\end{array}$ & $\begin{array}{l}\text { The transfer towards a } \\
\text { fine fusion policy, } \\
\text { intelligible with the } \\
\text { goals of energy policy } \\
\text { too and allowing more } \\
\text { vision to energy } \\
\text { economics, remains } \\
\text { highly needed [25]. } \\
\text { Energy is a key } \\
\text { contribution in the } \\
\text { industrialization } \\
\text { method of any country. } \\
\text { The example from such }\end{array}$ \\
\hline
\end{tabular}




\begin{tabular}{|l|l|}
\hline practices is that \\
effective industrial \\
policies need to be \\
attended by consistent \\
energy policies. \\
Effective industrial \\
policies require to be \\
accompanied by \\
consistent energy \\
policies, specially in a \\
country like Tanzania \\
which is amongst the \\
slightest electrified \\
nations in the globe \\
{$[26]$.}
\end{tabular}

\section{RESUlTS}

Based on the above points importance and their weightages, here the SAARC countries will be given weightage. If the SAARC country energy policies comply with the above points then it will be given higher weightage and if not then lesser. Each country points regarding their energy policy will be defined (reasoning) and then weightage will be given on it.

\section{A. Validation}

The following case validates the standard sustainable framework described above and discusses about the important parameters that needs to be present in a sustainable energy policy.

\section{B. Denmark's Case}

The resource of wind energy was considered as an opportunity to work towards an enhanced combination of sustainable fuels for the production of energy specifically by reducing the utilization of coal resource to support in progress of a developing industry. The buying needs premium fixed cost policies indulge values to allow straight forward approach to the grid for renewable energy manufacturers with a vibrant and financially reasonable systems of charging for grid access [27]. The aim was to device the energy act strategies that initiated from the year 1980 in line with the management's overall emission of carbon dioxide reducing targets. In the first step to entirely throw out the reserves of fossil fuels the government aims the drop in the utilization of gas, coal and oil reserves by around 33 percent between the year 2009-2020. The foremost aim of the Danish 2050 Energy plan is to gain $100 \%$ independence from fossil fuel resource in the country's energy mix by 2050 year. The target of RES is 30 percent in gross final energy consumption from 2010 to 2020 with feed- in tariff as a main aid strategy. The RE progress remained $17 \%$ of renewable energy share in the year 2005 and $22.2 \%$ in the year 2010. The green development agreement is between political parties founding a sustainable strategy for ecological policy in the industry of agriculture. This plan aims to lessen the greenhouse gas emissions from farming by $800000 t$ yearly. The feed-in law scheme for wind energy resource was lately restructured in 2009. In the year 2012 new regulations about net metering were issued. They contributed to completely or partially exempt the paying tariffs and duties for the amount of energy exported to the grid [28].

\section{Bangladesh}

According to the renewable resource policy, the government intends to produce 800 megawatt of energy from renewable energy by 2015 year. To motivate people to utilize renewable resource energy, the IDCOL i.e. infrastructure development company limited has installed a full of 0.2 million SHS i.e. solar home systems since May, in the year 2013. As a consequence, around 0.8 million folks in the rural areas are now having access to solar energy resource [29]. The sustainable energy development agency will assist demonstration of the latest technologies and upcoming business models for renewable resource energy and other technologies including the clean energy ones [30]. However it may require time to familiarize fuel resources other than gas for energy generation, the diversification of the fuel mix in energy sector is a serious need for elongated energy security in the country of Bangladesh [31].

\section{Bhutan}

The renewable energy resources lead the present energy supply in Bhutan. The fuel such as firewood is the main source of initial energy resource and it signifies the major share of utilization of energy resource. Another resource which is hydropower is the largest renewable energy resource in the country Bhutan and is the source for 99 percent of the country's energy production today [32]. Renewable energy feed-in tariffs for the mini, micro and small hydropower plants to be linked to grid, the Bhutan electricity authority shall establish feed-intariff to allow the injection of energy to the grid with guaranteed inducement [33]. The initial mandate of the energy policy should focus to deliver affordable, ecological friendly, safe and efficient energy to increase the living level of the folks. While the growth of solar resource energy is hindered due to finances, high costs and lack of suitable financing [34].

The above comparative review of Bhutan showed that it needs to improve the localization and diversification along with fostering innovation.

\section{E. India}

India is splendidly endowed with the wind and solar resource technology and can harness them in an advanced way to meet energy needs at decentralized positions. In the fresh auctions, wind and solar energy resource prices have atatined bus bar grid equivalence at the generation end [35]. However, the system of feed-in tariff is not novel to wind energy projects in India, big-scale solar energy resource has been mainly procured through an opposite auction procedure since the beginning of the national solar mission. Since the Gujarat trial, no government agencies in the country India have tried to utilize the feed-in tariff procedure to procure solar resource [36]. By the time of March 2007, the renewable resource energy, except hydro above 25 megawatts installed capacity, has taken part in 10,243 megawatts representing 7.7 percent of total energy installed capacity. There has been remarkable progress in wind energy and, with an installed capacity of over 8757 megawatts, India inhabits the fifth place worldwide [37]. 
The above comparative review of India showed that it needs to improve the diversification and broadening of industries.

\section{F. Nepal}

The mini hydro resource and solar photovoltaic are the most extensively used resource of renewable energy technologies in the rural electrification of the country Nepal and these were also the dual attentive technologies. The examination shows that here is a growing trend in the community participations in the mini hydro resource projects which can be observed as an indication that the rural electrification is going towards the business of sustainability [38]. The rising dependence to import the fuels of petroleum coupled with growing fuel cost in the globe's market is harshly impacting the already delicate economy of the nation [39]. The solar photovoltaic delivers a feasible option to meet electrical energy demand in the nonelectrified rural locations in country as well as completing the rising city energy demand. The renewable technology has been risingly implemented since the fitting of the first photovoltaic module in the year 1963 at the location of Bhadrapur Airport for the purpose of navigation [40].

The above comparative review of Nepal showed that it needs to improve the localization and reduction of fossil fuel resources.

\section{G. Maldives}

The resource of renewable energy does confronts some challenges such as absence of capabilities for design, development, implementation and management deficiency of economics available for the renewable resource energy uses and renewable resource based maintenance projects and also the deficiency of information on the choices available in renewable resource technology, statistics involved in renewable resource energy and in research [41]. The financial profits from the renewable resource energy system will originate from the scheme of feed in tariff mechanism for the renewable resource energy applied by the government of Ministry of environment and energy by the year 2013 of the expanse of feed in tariff grant delivered by the country Maldives is varied according to the kind of energy supply and the area [42]. To enhance the energy info net system there is a necessity of firming the existing systems of information and creating awareness of renewable resources; funding mechanisms for renewable resource projects, involving the regional structures of loan and technical aid to banks; policy assistances to operate the regulatory outlines that make renewable energy progress; and creating technical ability amongst players in the renewable resource field [43].

The above comparative review of Maldives showed that it needs to improve the localization and the Government economic framework.

\section{H. Pakistan}

An energy policy for progress of renewable resource was outlined in the year 2006 which was focused to deliver the sustainable energy to all customers involving those domestics which have not been delivered electricity and the resource of natural gas in remote and rural areas. The energy policy was prolonged for operation in the year 2011 and is still in usage.
The Pakistan government framed a policy named as Renewable Energy for power generation in the year 2006 which was focused on to be improved and is till now the initial planning framework in the matter. Currently, the nation's energy sector is fronting poorest ever lack of its history and the folks of the nation bear elongated term energy outages in twisting heat of seasonal variations and natural gas resource shortage in the cold season of winter [44]. In evolving latest energy generation projects, a priority shall be made to enhance and specific design of feed in tariff which shall establish the higher ceiling. Furtherly, the good bidding may be utilized to lower the price of production [45]. The additional resources of renewables involve solar resource power, wind resource energy, biomass energy, geothermal and waste to energy and their combined role in the mix of energy is not more than 5 percent understanding the reality that the resources of renewables are very costly at this level for nation such as Pakistan and the fundamental aim of the proposed plan is to develop the energy available at maximum rate to every customer [46]

The above comparative review of Pakistan showed that it needs to improve the economic framework and indigenization of multiple renewable resources along with fossil resource reduction.

\section{Sri Lanka}

It was discovered that absence of economic tools, high early price and deficit of resource supply certainty or accessibility are the major blockages for the resource of renewable energy technologies [47]. In the year 2010, the country Sri Lanka established a scheme of feed in tariff and has few of the maximum tariffs in the emerging globe now. The subsequent energy technologies are suitable up to a range of 10 watt. The resources of hydro energy, wind resource energy, biomass resource technology and the mini micro hydro resources involves that the tariffs are based on prices and specific to the technology, and the inventers have the choice of choosing either a three-level tariff or a plane tariff [48]. A suitable cost policy for the sector will be followed focusing on vital factors including price reflectivity, demand for aimed subsidies, and competition between locally generated services/goods in the local and global markets [49].

The above comparative review of Sri Lanka showed that it needs to improve the economic framework and indigenization of multiple renewable resources along with fossil resource reduction.

\section{CONCUSLION}

In this paper the comparative analysis of countries such as Germany and Denmark is considered as a progressive example in terms of attaining a sustainable energy policy. The country Pakistan has no prominent role from the renewable energy resources at nation wide stage but instead a main share of electricity is received from the fossil fuels reserves such as oil and gas. On the perkier side though, it may be considered that the nation makes wide use of river resources to produce the hydel resource power and compared to other nations it utilizes almost no coal resource for energy production in spite of around 175 billion tonnes resources being exposed in the southernmost domain. Between the reasons for absence of coal resource 
utilization in production are party-political issues and lack of investors for the purpose of deep mining that is needed. The resource of coal is also much in sulphur quantity, and the theme being discovered by the country scientists is gasification of coal resource as a replacement for of direct burning of it. The share of the renewable's resources needs to be amplified. A sequence of actions at both energy policy, societal and methodological levels are needed if the nation is to go into a sustainability situation by the end of 21 st century. As discussed above, it is attainable and economiclly feasible, to diversify the energy resources of country by keeping it away from the fossil reserves based on to green path. The major emphasis of the energy policy should aim to deliver sufficient capacity for energy generation at the less cost, and to avoid shortfalls by fulfilling the demand/supply gap. To boost up and make sure the utilization of indigenous natural resources of energy, which involves renewable resources, mankind power, contribution of local manufacturing and engineering competences and also to make sure that all shareholders are observed after in the procedure that is a win-win state for all. There should be a focus on to safeguard the environment. Also, to raise the deployment of renewable resource technologies in the country. To deliver further power supplies to assist in fulfilling the increasing country demand. To present the investment friendly inducements and enable renewable resource markets to entice private interest in renewable projects. There should be a proper policy to devise measures to assist the private sector in mobilizing, supporting and enabling the investment (public sector) in renewable resource projects.

\section{REFERENCES}

[1] Patlitzianas, K.D., et al., Sustainable energy policy indicators: Review and recommendations. Renewable Energy, 2008. 33(5): p. 966-973. \& Promotion of Renewable Energy. 20-24 June, 2011.

[2] Javed, A., Study to assess renewable energy development in South Asia ; Achievements and the way forward in the perspective of policies aand investment opportunities SAARC Energy Centre, Islamabad, December 2015.

[3] Oyedepo, S.O., Energy and sustainable development in Nigeria: the way forward. Energy, Sustainability and Society, 2012. 2(1): p. 15.

[4] Von Hippel, D., et al., Energy security and sustainability in Northeast Asia. Energy Policy, 2011. 39(11): p. 6719-6730.

[5] Khatib, H.e.a., World Energy Assessment - Energy and the Challenge of Sustainability (UNDESA - UNDP - WEA - WEC). Energy Security, 2000. Chapter 4 of J. Goldemberg et al(United Nations Development Programme, New York).

[6] Berry, T. and M. Jaccard, The renewable portfolio standard:: design considerations and an implementation survey. Energy Policy, 2001. 29(4): p. 263-277.

[7] Jacobsson, S. and V. Lauber, The politics and policy of energy system transformation - explaining the German diffusion of renewable energy technology. Energy policy, 2006. 34(3): p. 256-276.

[8] Menanteau, P., D. Finon, and M.-L. Lamy, Prices versus quantities: choosing policies for promoting the development of renewable energy. Energy policy, 2003. 31(8): p. 799-812.

[9] Couture, T.D., et al., Policymaker's guide to feed-in tariff policy design. 2010, National Renewable Energy Lab.(NREL), Golden, CO (United States).

[10] Li, X., Diversification and localization of energy systems for sustainable development and energy security. Energy policy, 2005. 33(17): p. 22372243.

[11] Ozturk, I., Energy dependency and security The role of effciency and renewable energy sources. april, 2014.
[12] Stirling, A., Diversity and ignorance in electricity supply investment: addressing the solution rather than the problem. Energy Policy, 1994. 22(3): p. $195-216$

[13] Ream, M.K., When it comes to energy, countries should mix it up. May 6, 2015.

[14] Sturm, C., Inside the Energiewende: Policy and Complexity in the German Utility Industry. Issues in Science and Technology, Winter 2017. 2(33).

[15] A. Gürhan Kök, K.S., Şafak Yücel, Impact of electricity pricing policies on renewable energy investments and carbon emissions. December 2 , 2016.

[16] Monasterolo, I. and M. Raberto, The impact of phasing out fossil fuel subsidies on the low-carbon transition. Energy Policy, 2019. 124: p. 355370.

[17] Kefford, B.M., et al., The early retirement challenge for fossil fuel power plants in deep decarbonisation scenarios. Energy policy, 2018. 119: p. 294-306.

[18] Lund, H. and B.V. Mathiesen, Energy system analysis of $100 \%$ renewable energy systems-The case of Denmark in years 2030 and 2050. Energy, 2009. 34(5): p. 524-531

[19] Morthorst, P.E., The development of a green certificate market. Energy policy, 2000. 28(15): p. 1085-1094.

[20] Foxon, T.J., et al., UK innovation systems for new and renewable energy technologies: drivers, barriers and systems failures. Energy policy, 2005. 33(16): p. 2123-2137.

[21] Chuang, M.C. and H.W. Ma, Energy security and improvements in the function of diversity indices-Taiwan energy supply structure case study. Renewable and Sustainable Energy Reviews, 2013. 24: p. 9-20.

[22] Asif, M. and T. Muneer, Energy supply, its demand and security issues for developed and emerging economies. Renewable and Sustainable Energy Reviews, 2007. 11(7): p. 1388-1413.

[23] Loiter, J.M. and V. Norberg-Bohm, Technology policy and renewable energy: public roles in the development of new energy technologies. Energy Policy, 1999. 27(2): p. 85-97.

[24] Lund, H. and W.W. Clark, Management of fluctuations in wind power and CHP comparing two possible Danish strategies. Energy, 2002. 27(5): p. 471-483.

[25] Verde, S., Everybody merges with somebody-The wave of M\&As in the energy industry and the EU merger policy. Energy policy, 2008. 36(3): p 1125-1133.

[26] Gussai Sheikheldin, B.D., Hezron Makundi, Energy policy for industrialization: Tanzania's big development challenge. Dec, 2018.

[27] Mourelatou, A., B.E. Research, and C. Limited, Renewable energies: success stories. 2001: Office for official publications of the european communities.

[28] Abdmouleh, Z., R.A. Alammari, and A. Gastli, Review of policies encouraging renewable energy integration \& best practices. Renewable and Sustainable Energy Reviews, 2015. 45: p. 249-262.

[29] Mustafa K. Mujeri, T.T.C.a.S.S., Energy Sector in Bangladesh: An agenda for reforms The International Institute for Sustainable Development March 2014.

[30] POWER DIVISION MINISTRY OF POWER, E.A.M.R.G.O.T.P.S.R.O.B., , and Renewable Energy Policy Of Bangladesh. DECEMBER, 182008

[31] Roland-Holst, H.G.a.D., Energy Policy Options for Sustainable Development in Bangladesh ADB Economics Working Paper Series, November, 2013.

[32] Policy and regulatory overviews Bhutan 2012. REEEP Policy Database (contributed by SERN for REEEP), 2012.

[33] Bhutan Renewable Energy Policy, 2011

[34] Department of Energy Ministery of Economic Affairs, R.G.o.B., Overview Of Energy Policies Of Bhutan. May, 2009.

[35] NITI Aayog, G.o.I., Draft National Energy Policy June 27, 2017

[36] Prateek, S., Feed-In Tariffs to Make a Comeback in India for Small Solar and Wind Projects. Feb 03, 2018.

[37] REN21, Renewables 2009 global status report. 
[38] Mainali, B. and S. Silveira, Financing off-grid rural electrification: country case Nepal. Energy, 2011. 36(4): p. 2194-2201.

[39] Reegle, Policy and regulatoy overviews- Nepal 2012.

[40] Nepal, R., Roles and potentials of renewable energy in less-developed economies: The case of Nepal. Renewable and Sustainable Energy Reviews, 2012. 16(4): p. 2200-2206.

[41] Promote renewable energy technologies (Policy no. 5, Maldives National Energy Policy and Strategy). 2010.

[42] Jung, T.Y., Y.T. Kim, and J.H. Hyun, An Economic Analysis of a Hybrid Solar PV-Diesel-ESS System for Kumundhoo, Maldives. Korea and the World Economy, 2017. 18(S1): p. 109-134.

[43] Timilsina, G.R. and K.U. Shah, Filling the gaps: Policy supports and interventions for scaling up renewable energy development in Small Island Developing States. Energy Policy, 2016. 98: p. 653-662.

[44] Aized, T., et al., Energy security and renewable energy policy analysis of Pakistan. Renewable and Sustainable Energy Reviews, 2018. 84: p. 155169.

[45] Pakistan, G.o., National Power Policy. 2013.

[46] Engr. Arshad h Abbasi, F.M., Amna Baig, Maha Kamal, Sdpi Pakistan Energy Vision 2035. 2014.

[47] Wijayatunga, P.D., et al., Strategies to overcome barriers for cleaner generation technologies in small developing power systems: Sri Lanka case study. Energy conversion and management, 2006. 47(9-10): p. 11791191.

[48] Reegle, Policy and regulatory overviews Sri Lanka 2012.

[49] Energy, M.O.P., The Gazette of the Democratic Socialist Republic of Sri Lanka. 11th May, 2008.

Maham Mujahid was born in Dictrict Peshawar, Khyber Pakhtunkwa, Pakistan on 5 January 1996, She has got her bachelor's degree in Biotechnology from University of Peshawar, Pakistan in 2017, currently she is getting her master's degree in Energy management and sustainability from US Pakistan Center for Adavnced Studies in Energy, University of Engineering and Technology Peshawar, Pakistan. Her research interest includes energy policies and comparative analysis of Saarc countries energy policies. 